\title{
Nutritional effects of the dietary inclusion of partially defatted Hermetia illucens larva meal in Muscovy duck
}

\author{
Marta Gariglio', Sihem Dabbou', Ilaria Biasato², Maria Teresa Capucchio', Elena Colombino', \\ Fuensanta Hernández ${ }^{3}$, Josefa Madrid³ ${ }^{3}$ Silvia Martínez ${ }^{3}$, Francesco Gai ${ }^{4}$, Christian Caimi², Sara Bellezza Oddon², \\ Marco Meneguz ${ }^{2}$, Angela Trocino ${ }^{5}$, Riccardo Vincenzi ${ }^{6}$, Laura Gasco ${ }^{2,4^{*}}$ (D) and Achille Schiavone ${ }^{1,4,7}$
}

\begin{abstract}
Background: The present work is aimed at evaluating the effect of different inclusion levels of a partially defatted black soldier fly (Hermetia illucens, L.; HI) larva meal for ducks. A total of 192 female 3-day-old Muscovy ducklings (Cairina moschata domestica, Canedins R71 L White, Grimaud Freres Selection, France) were divided into 4 groups, assigned 4 different dietary treatments (6 replicates/treatment and 8 birds/replicate) and reared from 3 to 50 days of age. $\mathrm{HI}$ larva meal was included at increasing levels $(0,3 \%, 6 \%$ and $9 \%, \mathrm{HIO}, \mathrm{HI} 3, \mathrm{HI} 6$ and $\mathrm{HI} 9$, respectively) in isonitrogenous and isoenergetic diets formulated for 3 feeding phases: starter (3-17 days of age), grower (18-38 days of age) and finisher (39-50 days of age). The growth performance and apparent total tract digestibility were evaluated during the trial using titanium dioxide as an inert marker ( $0.3 \%$ of inclusion). At 51 days of age, two birds per pen were slaughtered and histomorphological investigations were performed.

Results: The live weight and average daily gain showed a quadratic response to increasing $\mathrm{HI}$ meal in the grower period (minimum corresponding to the HI6 group). No effects of dietary inclusion levels were observed for the daily feed intake or feed conversion ratio. The apparent dry matter and organic matter digestibility were not affected by the dietary treatment. A linear decrease was observed for the crude protein apparent digestibility in the starter period (minimum for the HI9 groups). The ether extract apparent digestibility increased linearly during the grower and finisher periods (minimum for the HIO group). The morphometric indices were not influenced by the dietary treatments.

Conclusions: The inclusion of up to 9\% of HI partially defatted larva meal in the diet of ducks did not cause any effect on growth performance, as well as the apparent digestibility. Moreover, dietary HI inclusion preserved the physiological intestinal development.
\end{abstract}

Keywords: Black soldier fly, Digestibility, Ducks, Histopathology, Insect, Performance

\section{Introduction}

With an increase of $1.8 \%$ per year estimated until 2050, poultry production is one of the fastest growing sectors [1]. The production of duck meat has undergone a great expansion in recent years, passing from 2.23 million tonnes in 1996 to over 4.5 million tonnes in 2016 [2]. Duck

\footnotetext{
* Correspondence: laura.gasco@unito.it

2Department of Agricultural, Forest and Food Sciences, University of Turin, largo Paolo Braccini 2, Turin, Grugliasco 10095, Italy

${ }^{4}$ Institute of Science of Food Production, National Research Council, largo Paolo Braccini 2, Turin, Grugliasco 10095, Italy

Full list of author information is available at the end of the article
}

production plays an important role in Italy, with 3.27 thousand tonnes being produced in 2017 [3]. Duck farming has a great potential, since ducks are among the fastest producers of animal proteins and may contribute to the future nutritional needs of the growing world population [4].

The reduced availability of natural resources and the environmental impact of vegetable production require the research of alternative forms of protein for animal production. Considering the feeding habits of birds, including poultry (chicken, duck, turkey and geese), insects can represent a valuable alternative to the common

(c) The Author(s). 2019 Open Access This article is distributed under the terms of the Creative Commons Attribution 4.0 International License (http://creativecommons.org/licenses/by/4.0/), which permits unrestricted use, distribution, and reproduction in any medium, provided you give appropriate credit to the original author(s) and the source, provide a link to the Creative Commons license, and indicate if changes were made. The Creative Commons Public Domain Dedication waiver (http://creativecommons.org/publicdomain/zero/1.0/) applies to the data made available in this article, unless otherwise stated. 
protein sources, thanks to their nutritional characteristics [5]. The use of insects in feeds leads to advantages from both an environmental and nutritional point of view. Compared to conventional vegetable protein sources, insects rearing requires very little soil and water, and their low emission of greenhouse gases and ammonia implies an overall low environmental impact. A study conducted by an EU initiative PROteINSECT estimated that 1 ha of land can produce up to 150 tons of insect protein per year. Instead, 1 ha of land can produce less than 1 ton of soybean protein [6]. Moreover, insects can be reared on organic waste (such as fruit and vegetable) and can converting them into nutrients of high biological value, thanks to their high feed conversion efficiency $[7,8]$. Researchers have recently been evaluating the use of insects in animal feeding, and they have highlighted that insects could be used as a partial or total substitute for the currently used protein sources. The most promising species are Hermetia illucens (HI) [9-12], Musca domestica [13, 14] and Tenebrio molitor (TM) [15-18]. Thanks to the favourable nutrient composition of $\mathrm{HI}$, in terms of protein content (37-63\%), amino acid profile, fat content (7-39\%) and other macro- and micronutrients, it could be considered a valuable alternative to common protein sources, such as soybean meal (SBM) [19]. The effects of the inclusion of HI larva meal and oil on growth performance have been investigated in many studies [10-12, 20-22], with conflicting results being obtained. Only a few works are available regarding the digestibility of $\mathrm{HI}$ meal in poultry $[9,10,22-24]$ and these show extremely variable results in terms of dry matter (DM), crude protein (CP) and ether extract (EE). In these studies, nutrient digestibility was frequently influenced, according to the authors' interpretation, by the chitin content of the diets, which can negatively affect digestibility. Despite the limited availability of studies, the evaluation of the gut histomorphometry represents a relevant research topic, since it could affect the growth performance and the digestibility of a diet [25], depending on the protein source and level of the diet $[26,27]$. A recent study by Cutrignelli et al. [22] has found that the inclusion of HI larva meal in laying hen diets significantly affects the gut histomorphometry, resulting in a lower villi-to-crypt ratio than SBM group. The above-mentioned studies have shown a wide variability and more research is required to obtain a better understanding of the effect of the inclusion of $\mathrm{HI}$ in poultry diets.

To date, no research has investigated the possibility of including insect meal in duck diet. Therefore, the aim of the study was to evaluate the growth performance, digestibility and intestinal morphology of female broiler ducks (Cairina moschata domestica) fed diets including HI meal.

\section{Materials and methods}

\section{Birds and husbandry}

The present trial was performed at the poultry facility of the University of Turin (Italy). The experimental protocol (Prot. No. 380576, $4^{\text {th }}$ December 2017) was approved by the Bioethical Committee of the University of Turin (Italy). The poultry house was $7 \mathrm{~m}$ wide $\times 50 \mathrm{~m}$ long $\times 7$ $\mathrm{m}$ high, and was equipped with a waterproof floor and walls, completely covered by tiles and had an automatic ventilation system. A total of 192, 3-day-old, females Muscovy ducks (Canedins R71 L White, Grimaud Freres Selection, France) were housed in 24 pens and randomly allotted 4 dietary treatments, each group consisting of 6 pens as replicates with 8 birds per pen (average live weight (LW): $71.32 \pm 2.95 \mathrm{~g}$ ). Each pen was $1.20 \mathrm{~m}$ wide $\times 2.20 \mathrm{~m}$ long and was covered with rice hulls as litter. During the first 3 weeks, the animals were heated by infrared lamps. The lighting schedule was $23 \mathrm{~h}$ light $: 1 \mathrm{~h}$ darkness until day 3 of the trial, and thereafter the dark period was gradually increased to $6 \mathrm{~h}$ and maintained constant until slaughtering. The environmental parameters were monitored daily during the whole period of the trial.

\section{Diets}

Four dietary treatments were obtained in which increasing levels of a partially defatted HI larva meal (Hermetia Deutschland GmbH \& Co KG, Baruth/Mark, Germany) were included. In order to assess the effect of $\mathrm{HI}$ meal inclusion in the diets, HI meal was included as a substitute to gluten meal, a commonly used raw material in commercial duck feeding, which nutritional value is comparable to $\mathrm{HI}$ meal.

The control group (HI0) was fed a diet without insect meal (9\% inclusion of corn gluten meal); $3 \%, 6 \%$ and $9 \%$ of the gluten meal was substituted with HI larva meals in the HI3, HI6, and HI9 diets, respectively (Table 1).

The diets were isonitrogenous and isoenergetic and were formulated using the apparent metabolisable energy (AMEn) values for a partially defatted $\mathrm{HI}$, which had been calculated by Schiavone et al. [23] and according to INRA for the other ingredients [28] both for broiler chickens. The essential amino acids requirements were calculated with matrix value for digestible amino acids according to Schiavone et al. [23] for HI meal and Pingel et al. [29] for the other ingredients, for chickens and ducks, respectively. Feed and water were provided ad libitum throughout the trial. A 3-phase feeding program was applied: a starter diet (days 3 to 17), a grower diet (days 18 to 38 ) and a finisher diet (days 39 to 51 ).

\section{Chemical analysis of the $\mathrm{HI}$ meal and experimental diets}

The experimental diets were ground to pass through a $0.5-\mathrm{mm}$ sieve and stored in airtight plastic containers. 
Table 1 Ingredients ( $\mathrm{g} / \mathrm{kg}$ as fed) and nutrient composition (\%) of the experimental diets ${ }^{\mathrm{a}}$

\begin{tabular}{|c|c|c|c|c|c|c|c|c|c|c|c|c|}
\hline \multirow[t]{2}{*}{ Ingredients } & \multicolumn{4}{|c|}{ Starter period (days 3 to 17 ) } & \multicolumn{4}{|c|}{ Grower period (days 18 to 38 ) } & \multicolumn{4}{|c|}{ Finisher period (days 39 to 50) } \\
\hline & $\mathrm{HIO}$ & $\mathrm{HI3}$ & HI6 & $\mathrm{HI9}$ & $\mathrm{HIO}$ & $\mathrm{HI} 3$ & HI6 & $\mathrm{HI9}$ & $\mathrm{HIO}$ & $\mathrm{HI3}$ & HI6 & $\mathrm{HI9}$ \\
\hline Corn meal & 600.0 & 600.0 & 600.0 & 600.0 & 638.0 & 638.0 & 638.0 & 638.0 & 670.0 & 670.0 & 670.0 & 670.0 \\
\hline Soybean meal & 212.0 & 212.0 & 212.0 & 212.0 & 160.0 & 160.0 & 160.0 & 160.0 & 100.0 & 100.0 & 100.0 & 100.0 \\
\hline HI larva meal & 0.0 & 30.0 & 60.0 & 90.0 & 0.0 & 30.0 & 60.0 & 90.0 & 0.0 & 30.0 & 60.0 & 90.0 \\
\hline Bran & 42.5 & 42.5 & 42.5 & 42.5 & 36.3 & 36.3 & 36.3 & 36.3 & 66.2 & 66.2 & 66.2 & 66.2 \\
\hline Corn gluten meal & 90.0 & 60.0 & 30.0 & 0.0 & 90.0 & 60.0 & 30.0 & 0.0 & 90.0 & 60.0 & 30.0 & 0.0 \\
\hline Soybean oil & 16.5 & 16.5 & 16.5 & 16.5 & 28.5 & 28.5 & 28.5 & 28.5 & 34.5 & 34.5 & 34.5 & 34.5 \\
\hline Dicalcium phosphate & 10.0 & 10.0 & 10.0 & 10.0 & 13.0 & 13.0 & 13.0 & 13.0 & 4.0 & 4.0 & 4.0 & 4.0 \\
\hline Calcium carbonate & 8.0 & 8.0 & 8.0 & 8.0 & 14.0 & 14.0 & 14.0 & 14.0 & 17.4 & 17.4 & 17.4 & 17.4 \\
\hline Sodium chloride & 2.5 & 2.5 & 2.5 & 2.5 & 2.5 & 2.5 & 2.5 & 2.5 & 2.5 & 2.5 & 2.5 & 2.5 \\
\hline Sodium bicarbonate & 2.0 & 2.0 & 2.0 & 2.0 & 2.0 & 2.0 & 2.0 & 2.0 & 2.0 & 2.0 & 2.0 & 2.0 \\
\hline DL-methionine & 2.5 & 2.5 & 2.6 & 2.8 & 1.7 & 1.8 & 1.9 & 2.2 & 0.3 & 0.4 & 0.5 & 0.8 \\
\hline L-lysine & 3.9 & 3.9 & 3.8 & 3.6 & 3.9 & 3.8 & 3.7 & 3.4 & 3.0 & 2.9 & 2.8 & 2.5 \\
\hline Mineral-vitamin premix ${ }^{b}$ & 5.0 & 5.0 & 5.0 & 5.0 & 5.0 & 5.0 & 5.0 & 5.0 & 5.0 & 5.0 & 5.0 & 5.0 \\
\hline Choline chloride & 0.1 & 0.1 & 0.1 & 0.1 & 0.1 & 0.1 & 0.1 & 0.1 & 0.1 & 0.1 & 0.1 & 0.1 \\
\hline Optifos 250 bro & 1.0 & 1.0 & 1.0 & 1.0 & 1.0 & 1.0 & 1.0 & 1.0 & 1.0 & 1.0 & 1.0 & 1.0 \\
\hline Avizyme 1500x & 1.0 & 1.0 & 1.0 & 1.0 & 1.0 & 1.0 & 1.0 & 1.0 & 1.0 & 1.0 & 1.0 & 1.0 \\
\hline Titanium dioxide & 3.0 & 3.0 & 3.0 & 3.0 & 3.0 & 3.0 & 3.0 & 3.0 & 3.0 & 3.0 & 3.0 & 3.0 \\
\hline Total & 1,000 & 1,000 & 1,000 & 1,000 & 1,000 & 1,000 & 1,000 & 1,000 & 1,000 & 1,000 & 1,000 & 1,000 \\
\hline AMEnc, kcal/kg & 2,897 & 2,892 & 2,888 & 2,884 & 2,994 & 2,990 & 2,986 & 2,981 & 3,052 & 3,048 & 3,044 & 3,040 \\
\hline \multicolumn{13}{|l|}{ Nutrient composition $^{d}$} \\
\hline $\mathrm{DM}, \%$ & 89.3 & 89.8 & 90.1 & 89.7 & 88.8 & 89.2 & 89.1 & 89.1 & 88.7 & 89.0 & 89.3 & 88.9 \\
\hline $\mathrm{CP}, \% \mathrm{DM}$ & 25.1 & 24.7 & 25.2 & 24.8 & 23.0 & 22.5 & 22.5 & 22.4 & 20.2 & 20.2 & 20.1 & 20.1 \\
\hline $\mathrm{EE}, \% \mathrm{DM}$ & 4.7 & 4.8 & 4.9 & 5.1 & 6.2 & 6.2 & 6.4 & 6.6 & 7.3 & 7.4 & 7.6 & 7.7 \\
\hline$N D F, \% D M$ & 12.7 & 12.3 & 12.7 & 12.4 & 12.9 & 13.1 & 12.6 & 12.7 & 12.7 & 13.1 & 12.7 & 12.9 \\
\hline$A D F, \% D M$ & 3.4 & 3.5 & 3.7 & 3.3 & 3.5 & 3.5 & 3.7 & 3.5 & 3.4 & 3.5 & 3.5 & 3.4 \\
\hline Ash, \% DM & 5.6 & 6.0 & 5.6 & 5.8 & 7.8 & 7.5 & 7.5 & 8.0 & 6.5 & 6.4 & 6.9 & 6.7 \\
\hline \multicolumn{13}{|c|}{ Fatty acid composition, \% of total FAME } \\
\hline SFA & 19.0 & 20.7 & 23.9 & 26.9 & 17.7 & 20.2 & 22.5 & 25.5 & 17.3 & 19.4 & 22.2 & 23.7 \\
\hline MUFA & 27.6 & 26.1 & 25.5 & 24.6 & 25.8 & 24.9 & 24.2 & 23.5 & 24.9 & 24.8 & 23.8 & 23.8 \\
\hline PUFA & 52.8 & 52.6 & 49.9 & 47.9 & 55.9 & 54.4 & 52.7 & 50.5 & 57.2 & 55.3 & 53.5 & 51.8 \\
\hline PUFA/SFA & 2.78 & 2.54 & 2.08 & 1.78 & 3.15 & 2.69 & 2.34 & 1.98 & 3.31 & 2.85 & 2.40 & 2.18 \\
\hline$\sum n-3$ & 3.3 & 3.4 & 3.4 & 3.3 & 4.1 & 4.2 & 4.1 & 4.1 & 4.5 & 4.5 & 5.3 & 5.0 \\
\hline$\sum n-6$ & 49.1 & 48.9 & 46.1 & 44.3 & 51.6 & 49.9 & 48.2 & 46.1 & 52.3 & 50.4 & 47.9 & 46.4 \\
\hline$\sum n-6 / \Sigma n-3$ & 14.88 & 14.38 & 13.56 & 13.42 & 12.58 & 11.88 & 11.76 & 11.24 & 11.62 & 11.20 & 9.04 & 9.28 \\
\hline
\end{tabular}

HI Hermetia illucens, AMEn apparent metabolisable energy, DM dry matter, $C P$ crude protein, EE ether extract, NDF neutral detergent fiber, $A D F$ acid detergent fiber, FAME fatty acid methyl esters, SFA saturated fatty acids, MUFA monounsaturated fatty acids, PUFA polyunsaturated fatty acids

${ }^{a}$ Four dietary treatments: $\mathrm{HIO}=$ control; $\mathrm{HI} 3=3 \%$ inclusion level of Hermetia illucens; $\mathrm{HI} 6=6 \%$ inclusion level of Hermetia illucens; $\mathrm{HI} 9=9 \%$ inclusion level of Hermetia illucens ${ }^{\mathrm{b}}$ Mineral-vitamin premix: vitamin $\mathrm{A}$ (retinyl acetate), 12,500 IU; vitamin $\mathrm{D}_{3}$ (cholecalciferol), 3,500 IU; vitamin $\mathrm{E}$ ( $D L$-a-tocopheryl acetate), $40 \mathrm{mg}$; vitamin $\mathrm{K}$ (menadione sodium bisulfite), $2.0 \mathrm{mg}$ biotin, $0.20 \mathrm{mg}$; thiamine, $2.0 \mathrm{mg}$; riboflavin, $6.0 \mathrm{mg}$; pantothenate, $15.21 \mathrm{mg} ; \mathrm{niacin}, 40.0 \mathrm{mg}$; choline, $750.0 \mathrm{mg}$ pyridoxine, $4.0 \mathrm{mg}$; folic acid, $0.75 \mathrm{mg}$; vitamin $\mathrm{B}_{12}, 0.03 \mathrm{mg}$; Mn, $70 \mathrm{mg}$; Zn, $62.15 \mathrm{mg} ; \mathrm{Fe}, 50.0 \mathrm{mg}$; Cu, $7.0 \mathrm{mg} ; \mathrm{l}, 0.25 \mathrm{mg} ; \mathrm{Se}, 0.25 \mathrm{mg}$

${ }^{\mathrm{C}}$ Calculated according to Schiavone et al. [23] for $\mathrm{HI}$ meal and INRA [28] for the other ingredients

${ }^{\mathrm{d}}$ The chemical analyses were carried out on three replicates of each feed sample

HI larva meal and the experimental diets were analysed for DM (AOAC, method number \#934.01), ash (AOAC, method number \#942.05), CP (AOAC, method number \#984.13), neutral detergent fiber (NDF; AOAC, method number \#2002.04) and acid detergent fiber (ADF; AOAC method number \#973.18) [30]. The EE (AOAC, method number \#2003.05) was determined according to International AOAC [31]. 
The chitin content of HI meal was determined according to Finke et al. [32] using ADF adjusted for its nitrogen content.

In order to perform the amino acids determination in HI meal, samples were prepared using a 22-h hydrolysis step in $6 \mathrm{~mol} / \mathrm{L} \mathrm{HCl}$ at $112{ }^{\circ} \mathrm{C}$ under a nitrogen atmosphere. Performic acid oxidation occurred prior to acid hydrolysis for methionine and cystine. The amino acids in hydrolysate was determined by means of HPLC after postcolumn derivatization, according to the procedure described by Madrid et al. [33]. Tryptophan was not determined. The lipid extraction and fatty acids profiling of the experimental diets [34-36] were carried out at the laboratory of the Department of Animal Medicine, Production and Health, University of Padua, Legnaro, Italy according to the method of Christie [37]. All the analysis were performed in triplicate (Table 1).

The chemical composition of the HI meal was the following: DM, $92.41 \mathrm{~g} / \mathrm{kg}$; CP, 56.71\% DM; EE, 10.70\% DM; ash, $16.38 \% \mathrm{DM}$; chitin, 6.43\% DM; $D L$-methionine, $0.63 \%$ DM and $L$-lysine, $1.89 \%$ DM.

\section{Growth performance}

Birds were individually labeled with a wing mark and weighed at their arrival. Mortality and clinical signs of illness were monitored daily throughout the trial. The live weight (LW) of the animals was recorded at an individual level at the beginning and at the end of each feeding phase $(3,17,38$ and 50 days of age), and the feeds were removed $2 \mathrm{~h}$ before the birds were weighed. The average daily gain (ADG) and average daily feed intake (DFI) were recorded at a pen level at the end of each growth period.

The feed conversion ratio (FCR) was calculated for each growth period and for the overall experimental period. All the measurements were made using electronic scales (Sartorius-Signum ${ }^{\circ}$, Bovenden, Germany).

\section{Digestibility trial}

The digestibility trial was performed at the end of each feeding phase using titanium dioxide $\left(\mathrm{TiO}_{2}, 0.3 \mathrm{~g} / \mathrm{kg}\right)$ as an indigestible marker in each experimental diet (Table 1), in order to evaluate the apparent total tract digestibility coefficients (ATTDC). The Kaczmarek et al. [38] method was used to collect the excreta, with slight modifications, as reported by Dabbou et al. [39]. Briefly, all the birds were removed from each pen and housed in wire-mesh cages ( $n=6$ replicates) for approximately $1 \mathrm{~h} / \mathrm{d}$ for four consecutive days to collect fresh excreta samples.

After collection, the excreta samples, from which the feathers and litter had been removed, were immediately frozen at $-20^{\circ} \mathrm{C}$. At the end of each collection period, the excreta were pooled, lyophilized, grounded and stored at $4{ }^{\circ} \mathrm{C}$. All the analyses were carried out on two replicates for each sample. The ATTDC was evaluated for DM, CP,
EE and OM. The uric acid (UA) content in the excreta samples was determined spectrophotometrically (UNICAN UV-Vis Spectrometry, Helios Gamma, the United Kingdom) according to the Marquardt method [40]. The nitrogen contained in uric acid is the 33.33\%. The CP amount in the excreta ( $\mathrm{CP}$ corrected) was calculated using the excreta $\mathrm{CP}$, corrected for UA as follows:

$\mathrm{CP}$ corrected $=($ total nitrogen $-\mathrm{UA}-$ nitrogen $) \times 6.25$.

The $\mathrm{TiO}_{2}$ content was measured on a UV spectrophotometer (UNICAN UV-vis Spectrometry, Helios Gamma, the United Kingdom) following the Myers et al. [41] method .

The ATTDC of the dietary nutrients was calculated using the following method [42]:

$$
A T T D C X_{\text {diet }}=\left[\frac{(\text { Total } X \text { ingested }- \text { total } X \text { excreted })}{\text { total } X \text { ingested }}\right]
$$

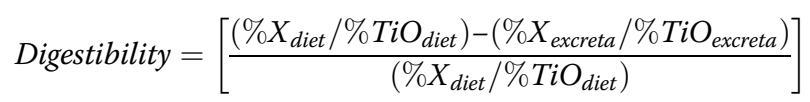

where $X$ represents DM, CP, EE or OM.

\section{Slaughtering procedures}

At 50 days of age, the final LW of the birds was recorded individually and 12 ducks per diet (two birds per pen) were chosen on the basis of the LW pen average and identified by means of a shank ring. Then the feed was removed and, after $12 \mathrm{~h}$ of fasting (at 51 days of age), the selected animals were transferred to a commercial abattoir and slaughtered by electrical stunning and bleeding, according to the standard EU regulations. The plucked and eviscerated carcasses were obtained, the head, neck and feet were removed.

\section{Histomorphological investigations}

Gut segments (approximately $5 \mathrm{~cm}$ in length, 12 animals per each group) of the duodenum, jejunum and ileum were sampled during slaughtering and flushed with $0.9 \%$ saline to remove all the contents. The collected intestine segments were the loop of the duodenum, the tract before Meckel's diverticulum (jejunum) and the tract before the ileocolic junction (ileum). The gut samples were fixed in a $10 \%$ buffered formalin solution, routinely embedded in paraffin wax blocks, sectioned at a $5-\mu \mathrm{m}$ thickness, mounted on glass slides and stained with Haematoxylin \& Eosin (HE) for morphometric analysis. The evaluated morphometric indices were as follows: villus height (Vh, from the tip of the villus to the crypt), crypt depth $(\mathrm{Cd}$, from the base of the villus to the submucosa) and the villus height-to-crypt depth $(\mathrm{Vh} / \mathrm{Cd})$ ratio [27]. Morphometric analyses were performed on 10 
well-oriented and intact villi and 10 crypts chosen from the duodenum, jejunum and ileum [26].

\section{Statistical analysis}

The statistical analyses were performed using the SPSS software package (version 21 for Windows, SPSS Inc., Chicago, IL, USA). The mortality rate was analysed by means of a Chi-square test, using the HIO group as the reference. Shapiro-Wilk's test established normality or non-normality of distribution. The assumption of equal variances was assessed by means of Levene's homogeneity of variance test. The experimental unit was the pen for growth performance and digestibility, while the duck was used for the intestinal morphology. The collected data were tested by means of one-way ANOVA. Polynomial contrasts were used to test the linear and quadratic responses to increases in the $\mathrm{HI}$ inclusion level in the diet. Intestinal morphometric indices were analysed by fitting a general linear mixed model (GLMM). GLMM allowed the morphometric indices $(\mathrm{Vh}, \mathrm{Cd}$ and $\mathrm{Vh} / \mathrm{Cd}$, separately) to depend on three fixed factors (diet, intestinal segment and interaction between diet and intestinal segment). Animal was included as a random effect to account for repeated measurements in the same duck. The interactions between the levels of the fixed factors were evaluated by means of pairwise comparisons.

Differences among treatments were considered statistically significant when the $P$ values $\leq 0.05$.

\section{Results}

\section{Growth performance}

The cumulative mortality rates of the HIO (4.16\%), HI3 (2.08\%), HI6 (2.08\%) and HI9 (2.08\%) groups were not influenced by the dietary treatments $(P>0.05)$. The growth performances of the broiler ducks are summarized in Table 2. Overall LW was not influenced by the dietary treatments $(P>0.05)$, except at 38 days of age, when a quadratic response was observed in LW for increasing $\mathrm{HI}$ meal levels with a minimum being observed for the HI6 group $(P<0.05)$.

ADG was not affected by the dietary treatments $(P>0.05)$, with the exception of the HI6 group in the second period (18-38 days of age), where the ADG showed a quadratic response $(P<0.05)$. DFI and FCR were not affected by the dietary treatment nor in the different feeding phases or over the whole experimental trial $(P>0.05)$.

\section{Digestibility trial}

The apparent digestibility coefficients are reported in Table 3 . DM digestibility was not affected by the dietary treatment throughout the trial, as well as the $\mathrm{OM}$ $(P>0.05)$. In the starter period (3-17 days of age) the CP digestibility decreased linearly with a minimum corresponding to the HI9 groups $(P<0.05) \quad(-4.11 \%$ compared to HIO, respectively), whereas the EE digestibility decreased linearly with the inclusion of $\mathrm{HI}$ in the diets $(P<0.05)$.

Table 2 Effect of the dietary HI larva meal inclusion on the growth performance of female ducks $(n=6)$

\begin{tabular}{|c|c|c|c|c|c|c|c|c|}
\hline \multirow[t]{2}{*}{ Items } & \multirow[t]{2}{*}{ Age } & \multicolumn{4}{|c|}{ Dietary treatments ${ }^{a}$} & \multirow[t]{2}{*}{ SEM } & \multicolumn{2}{|l|}{$P$-value } \\
\hline & & $\mathrm{HIO}$ & $\mathrm{HI3}$ & $\mathrm{HI6}$ & $\mathrm{HI9}$ & & Linear & Quadratic \\
\hline \multirow[t]{4}{*}{ LW, g } & $3 d$ & 70.70 & 70.41 & 72.65 & 71.51 & 0.60 & 0.405 & 0.733 \\
\hline & $17 \mathrm{~d}$ & 575.44 & 567.31 & 572.56 & 575.74 & 4.76 & 0.893 & 0.582 \\
\hline & $38 d$ & 1906.79 & 1861.96 & 1797.10 & 1900.12 & 14.18 & 0.426 & 0.005 \\
\hline & $50 \mathrm{~d}$ & 2540.57 & 2511.14 & 2456.14 & 2554.84 & 20.13 & 0.946 & 0.123 \\
\hline \multirow[t]{4}{*}{$A D G, g / d$} & $3-17 d$ & 36.05 & 35.49 & 35.71 & 36.02 & 0.32 & 0.974 & 0.529 \\
\hline & $18-38 d$ & 63.40 & 61.65 & 58.31 & 63.07 & 0.69 & 0.417 & 0.011 \\
\hline & $39-50 d$ & 52.81 & 54.10 & 54.92 & 54.56 & 1.14 & 0.582 & 0.738 \\
\hline & $3-50 d$ & 52.55 & 51.93 & 50.71 & 52.84 & 0.43 & 0.926 & 0.125 \\
\hline \multirow[t]{4}{*}{$D F I, g / d$} & $3-17 d$ & 53.69 & 53.45 & 52.16 & 51.85 & 0.59 & 0.226 & 0.979 \\
\hline & $18-38 d$ & 142.03 & 139.06 & 136.99 & 139.92 & 1.28 & 0.481 & 0.273 \\
\hline & $39-50 d$ & 167.48 & 170.82 & 160.32 & 171.80 & 2.83 & 0.924 & 0.485 \\
\hline & $3-50 d$ & 120.58 & 121.32 & 117.58 & 121.48 & 1.20 & 0.927 & 0.530 \\
\hline \multirow[t]{4}{*}{$F C R, g / g$} & $3-17 d$ & 1.49 & 1.51 & 1.46 & 1.44 & 0.01 & 0.099 & 0.489 \\
\hline & $18-38 d$ & 2.24 & 2.26 & 2.35 & 2.22 & 0.03 & 0.913 & 0.159 \\
\hline & $39-50 d$ & 3.17 & 3.17 & 2.93 & 3.18 & 0.051 & 0.639 & 0.220 \\
\hline & $3-50 d$ & 2.29 & 2.34 & 2.32 & 2.30 & 0.019 & 0.925 & 0.406 \\
\hline
\end{tabular}

HI Hermetia illucens, SEM standard error of the mean, $L W$ live weight, $A D G$ average daily gain, DFI daily feed intake, FCR feed conversion ratio ${ }^{a}$ Four dietary treatments: $\mathrm{HIO}=$ control; $\mathrm{HI} 3=3 \%$ inclusion level of Hermetia illucens; $\mathrm{HI} 6=6 \%$ inclusion level of Hermetia illucens; $\mathrm{HI} 9=9 \%$ inclusion level of Hermetia illucens 
In the periods from 18 to 38 days of age and from 39 to 50 days of age, the EE digestibility showed a linear increase, with a maximum corresponding to the HI9 group $(P<0.001)(+1.94 \%$ and $+3.05 \%$ compared to HIO in the grower and finisher periods, respectively). However, CP digestibility was not affected by the dietary treatments in the grower and finisher periods $(P>0.05)$.

\section{Histomorphological investigations}

The effects of the diet, gut segment and interaction between the diet and gut segment on the gut morphometric indices of the ducks are summarized in Table 4. The intestinal segment significantly affected $\mathrm{Vh}, \mathrm{Cd}$ and $\mathrm{Vh} / \mathrm{Cd}$ $(P<0.001)$. On the other hand, no influence of diet or interaction between the diet and intestinal segment $(P>0.05)$ were observed on the morphometric indices. The duodenum showed higher $\mathrm{Vh}$ and $\mathrm{Cd}$ values $(P<0.05$ and $P<0.01$, respectively) than the ileum, and the morphometric indices were also greater $(P<0.05$ and $P<0.01$, respectively) in the jejunum than in the ileum. The duodenum also showed a greater $\mathrm{Vh} / \mathrm{Cd}(P<0.05)$ than the other gut segments.

\section{Discussion}

\section{Growth performance}

Currently, no literature is available regarding the use of insect meals in duck feeding. For this reason, all the comparisons with literature data referred to other poultry species fed with HI meals and other insect meals.

The final LW of the birds was in line with the weight reported by Pingel et al. [29]. The results showed that HI meal could be a valuable alternative to corn gluten meal, and HI meal can be included in duck diets by as much as $9 \%$ without any negative effects on the final LW, ADG, DFI and FCR of the animals. Despite the lower LW and ADG of HI6 birds in the grower period (18-38 days of age), DFI and FCR were not influenced by the dietary treatment, and the final LW of the HI6 group was in line with the weight of the other treatments. Similarly, Cullere et al. [10] did not observe any differences in the final LW of broiler quails (Coturnix coturnix japonica) fed two different diets at $10 \%$ and $15 \%$ of inclusion levels of $\mathrm{HI}$ meal (in substitution of SBM protein and oil). Our results also agree with what Bovera et al. [24] previously reported for laying hens fed $25 \%$ and $50 \% \mathrm{HI}$ in substitution of SBM $(73 \mathrm{~g} / \mathrm{kg}$ and $146 \mathrm{~g} / \mathrm{kg}$ of inclusion, respectively), thus showing that LW and DFI were not influenced by the dietary treatments. The inclusion of up to $10 \%$ of HI larva meal in the diet of broiler chickens influenced their final LW and also improved the DFI of chicks in the starter period [12]. As far as other insect species with potential interest as feeds are concerned, Adenjii [13] did not observe any dietary effects on the performance of broiler chickens when groundnut cake was substituted with housefly maggot (M. domestica) meal. Biasato et al. [16], Ramos-Elorduy et al. [43] and Bovera et al. [44] also reported that the inclusion of TM meal in broiler chicken diets (from $5 \%$ to $15 \%$ of inclusion) did not affect the final LW and DFI of the birds. On the other hand, the replacement of SBM with $25 \%$ and $50 \%$ of HI meal (100 and $190 \mathrm{~g} / \mathrm{kg}$ of inclusion, respectively) and 25\% TM meal $(120 \mathrm{~g} / \mathrm{kg}$ of inclusion) in Barbary partridge (Alectoris barbara) resulted in a higher LW than the control [45]. Finally, the results reported by Khan et al. [46], pertaining to broiler chicks fed with silkworm (Bombyx mori), housefly maggot and TM in substitution of SBM

Table 3 Effect of the dietary inclusion of HI larva meal on the nutrients apparent digestibility of Muscovy ducks $(n=6)$

\begin{tabular}{|c|c|c|c|c|c|c|c|c|}
\hline \multirow[t]{2}{*}{ Age } & \multirow{2}{*}{$\begin{array}{l}\text { Apparent } \\
\text { digestibility }\end{array}$} & \multicolumn{4}{|c|}{ Dietary treatments $^{a}$} & \multirow[t]{2}{*}{ SEM } & \multicolumn{2}{|l|}{$P$-value } \\
\hline & & $\mathrm{HIO}$ & $\mathrm{HI} 3$ & $\mathrm{HI6}$ & $\mathrm{HI9}$ & & Linear & Quadratic \\
\hline \multirow[t]{4}{*}{$3-17 d$} & $\mathrm{DM}$ & 0.960 & 0.960 & 0.960 & 0.953 & 0.002 & 0.174 & 0.315 \\
\hline & $\mathrm{CP}$ & 0.852 & 0.872 & 0.828 & 0.817 & 0.007 & 0.010 & 0.195 \\
\hline & $\mathrm{EE}$ & 0.945 & 0.967 & 0.963 & 0.962 & 0.002 & 0.003 & 0.085 \\
\hline & $\mathrm{OM}$ & 0.963 & 0.963 & 0.966 & 0.962 & 0.001 & 0.853 & 0.453 \\
\hline \multirow[t]{4}{*}{$18-38 d$} & $\mathrm{DM}$ & 0.953 & 0.956 & 0.962 & 0.960 & 0.002 & 0.086 & 0.511 \\
\hline & $\mathrm{CP}$ & 0.800 & 0.802 & 0.802 & 0.828 & 0.005 & 0.085 & 0.269 \\
\hline & $\mathrm{EE}$ & 0.958 & 0.966 & 0.968 & 0.977 & 0.002 & $<0.001$ & 0.891 \\
\hline & $\mathrm{OM}$ & 0.958 & 0.964 & 0.967 & 0.963 & 0.001 & 0.215 & 0.168 \\
\hline \multirow[t]{4}{*}{$39-50 d$} & $\mathrm{DM}$ & 0.943 & 0.948 & 0.952 & 0.953 & 0.002 & 0.099 & 0.703 \\
\hline & $\mathrm{CP}$ & 0.733 & 0.682 & 0.715 & 0.718 & 0.012 & 0.913 & 0.259 \\
\hline & EE & 0.953 & 0.958 & 0.965 & 0.983 & 0.003 & $<0.001$ & 0.092 \\
\hline & $\mathrm{OM}$ & 0.950 & 0.953 & 0.958 & 0.958 & 0.002 & 0.072 & 0.642 \\
\hline
\end{tabular}

HI Hermetia illucens, SEM standard error of the mean, DM dry matter, CP crude protein, EE ether extract

${ }^{\mathrm{a}}$ Four dietary treatments: $\mathrm{HIO}=$ control; $\mathrm{HI} 3=3 \%$ inclusion level of Hermetia illucens; $\mathrm{HI} 6=6 \%$ inclusion level of Hermetia illucens; $\mathrm{HI} 9=9 \%$ inclusion level of Hermetia illucens 
Table 4 Intestinal morphometric indices in the ducks in relation to diet and intestinal segment $(n=12$, end of the trial)

\begin{tabular}{|c|c|c|c|c|c|c|c|c|c|c|c|c|}
\hline \multirow[t]{2}{*}{ Index } & \multicolumn{4}{|c|}{$\operatorname{Diet}(D)^{d}$} & \multicolumn{3}{|c|}{ Intestinal segment (IS) } & \multicolumn{2}{|l|}{ SEM } & \multicolumn{3}{|c|}{$P$-value } \\
\hline & $\mathrm{HIO}$ & HI3 & HI6 & HI9 & DU & $\mathrm{JE}$ & IL & $D$ & IS & D & IS & $D \times I S$ \\
\hline $\mathrm{Vh}, \mathrm{mm}$ & 1.55 & 1.51 & 1.52 & 1.63 & $2.12^{\mathrm{a}}$ & $1.41^{\mathrm{b}}$ & $1.14^{c}$ & 0.06 & 0.06 & 0.442 & $<0.001$ & 0.508 \\
\hline $\mathrm{Cd}, \mathrm{mm}$ & 0.16 & 0.14 & 0.15 & 0.15 & $0.18^{\mathrm{a}}$ & $0.15^{\mathrm{b}}$ & $0.13^{c}$ & 0.01 & 0.01 & 0.346 & $<0.001$ & 0.782 \\
\hline $\mathrm{Vh} / \mathrm{Cd}$ & 9.80 & 11.06 & 10.67 & 10.83 & $12.62^{\mathrm{a}}$ & $9.67^{b}$ & $9.48^{\mathrm{b}}$ & 0.60 & 0.45 & 0.469 & $<0.001$ & 0.966 \\
\hline
\end{tabular}

$V h$ villus height, $C d$ crypt depth, $V h / C d$ villus height-to-crypt depth ratio

The means with different superscript letters $\left({ }^{a}, b, c\right)$ within the same row per fixed effect (i.e. diet, intestinal segment) differ significantly $(P<0.05)$

${ }^{\mathrm{d}}$ Four dietary treatments: $\mathrm{HIO}=$ control; $\mathrm{HI} 3=3 \%$ inclusion level of Hermetia illucens; $\mathrm{HI} 6=6 \%$ inclusion level of Hermetia illucens; $\mathrm{HI} 9=9 \%$ inclusion level of Hermetia illucens

'Three intestinal segments: $D U$ duodenum, JE jejunum, IL ileum

(7.8\%, $8.0 \%$ and $8.1 \%$ of inclusion, respectively), pointed out a higher LW in insect-fed chicks than in the control. In this trial, the FCR was not affected by the dietary treatments, according to the results of Elwert et al. [47] and Cullere et al. [10] pertaining to broiler chickens and broiler quails, respectively, fed with increasing levels of defatted HI meal. On the contrary, an improved FCR was observed in Barbary partridge fed diets with 25\% and $50 \%$ of substitution of SBM with $\mathrm{HI}$ and TM meal [45]. An improved FCR was also reported by Khan et al. [46] (silkworm, housefly maggot, TM) and Bovera et al. [44] (TM), who found that the FCR of broiler chickens was lower in chicks fed insect meal than the control diet with SBM.

The use of HI larva meal as a substitute to corn gluten meal results to be suitable in Muscovy ducks feeding. During the whole experimental period, the growth performances observed in the present study were not influenced by dietary inclusion levels of HI meal, as already observed by other researches in quails and laying hens [10, 24]. Furthermore, the absence of gut histomorphological alterations can also explain the growth performance results, as well as the slightly affected nutrient digestibility.

\section{Digestibility trial}

The herein obtained results show that the inclusion of $\mathrm{HI}$ larva meal in Muscovy duck diets partially affected the apparent digestibility coefficients of the nutrients. Consistently with our results, Cullere et al. [10] did not report any differences in DM and OM total tract apparent digestibility in broiler quails as a result of the $\mathrm{HI}$ inclusion level in the diet. On the contrary, in laying hens fed 17\% HI meal in the diet, the apparent ileal digestibility of DM was lower in the group fed HI meal than in the control [22]. Results reported by Bovera et al. [24] showed that the inclusion of $\mathrm{HI}$ meal by up to $7.3 \%$ in laying hen diets did not affect the apparent DM ileal digestibility, compared to the control with vegetable protein meal, whereas the inclusion of $14.6 \%$ reduced the apparent DM ileal digestibility. In another study, the use of TM in broiler chicken diets worsened the apparent ileal DM digestibility compared to the control with SBM [44].
In our trial, the $\mathrm{CP}$ and $\mathrm{EE}$ apparent digestibility in the starter period (3-17 days of age) showed an opposite linear trend, with a reduction in CP digestibility (up to $-3.5 \%$ in HI9, compared to the control) and an improvement in EE digestibility (+ 2.0 in HI9, compared to the control) following the increasing inclusion levels of $\mathrm{HI}$ meal in the diet. The lower CP digestibility for the HI6 and HI9 groups in the starter period could be related to the higher chitin content of the diet, because of the higher inclusion level of $\mathrm{HI}$ meal [48]. In fact, Cutrignelli et al. [22] and Bovera et al. [24] also observed a reduction in the apparent ileal CP digestibility of laying hens compared to the control diet with SBM, and explained this result as a consequence of the presence of chitin in the diet. Indeed, De Marco et al. [9] assumed that the chitin, the structural component of the exoskeleton of insects, can negatively affect the nutrient digestibility, resulting as an indigestible fiber for domestic poultry. However, no differences in $\mathrm{CP}$ total tract apparent digestibility were reported by Cullere et al. [10] for broiler quails, after a substitution of protein/fat sources with $\mathrm{HI}$ larva meal of up to $15 \%$ of inclusion. However, in our trial, the apparent $\mathrm{CP}$ digestibility was similar during the grower (18-38 days of age) and finisher (39-50 days of age) periods, thus suggesting an adaptation to the chitin levels in the diet. The studies conducted by Tabata et al. $[49,50]$ showed that the birds have acid chitinase genes in their genome. In particular, in poultry (such as ducks), the acid chitinase is expressed mainly at the level of the glandular stomach. The level of acid chitinase mRNA in stomach tissue is regulated by feeding behaviour, which was higher in omnivorous species than in herbivorous and carnivorous species [50]. Moreover, it could be speculated that the chitin level in the diet could influence the acid chitinase expression with an overall improvement in feed digestibility.

In our trial, the $\mathrm{EE}$ apparent digestibility was higher in $\mathrm{HI}$ groups than the control group. However, despite this positive result, the EE apparent digestibility was only $2.2 \%$ and $1.9 \%$ higher than the control in the starter and grower periods respectively (3-17 and 18-38 days of age) and $3.0 \%$ higher than the control in the finisher period (39-50 days of age). This result partially agrees with the results of Cullere et al. [10], who found that the EE total tract 
apparent digestibility in broiler quails fed with a $15 \%$ inclusion level of $\mathrm{HI}$ was higher than a $10 \%$ group, but similar to the control diet. On the other hand, Cutrignelli et al. [22] and Bovera et al. [24] found that the apparent ileal EE digestibility in laying hens was similar for HI meal- and SBM-fed birds. The linear increase in EE digestibility is not supported by the fatty acids profile, in particular by the polyunsaturated fatty acids (PUFA) content, that is usually related to an EE digestibility improvement [51]. Indeed, in the present study the dietary PUFA content, as well as the ratio polyunsaturated fatty acids/saturated fatty acids (PUFA/SFA ratio), decreased following the HI larva meal inclusion (Table 1). The highest EE digestibility at the maximum inclusion level (HI9 group) could be related to the overall amount of EE in the diets $(+7.84 \%,+6.06 \%$ and $+5.19 \%$ higher in HI9 group than HIO group in starter, grower and finisher periods, respectively) [52].

As a whole, the absent or moderate effects on nutrient ATTDC had no impact on the ducks' growth performances, without affecting final LW, ADG, DFI and FCR.

\section{Histomorphological investigations}

Dietary HI meal inclusion did not affect the gut morphology of the ducks of our study. Since the rapid growth of chickens has been reported to strictly depend on the morphological and functional integrity of the digestive tract [25], it is reasonable to hypothesize that insect meal utilization does not negatively influence gut development and, as a consequence, animal performance. The greater mucosal development observed in the duodenum than in the other gut segments is also in agreement with the previous studies available on broilers [11, 14-17, 53, 54], thus suggesting that insect meal utilization leads to the preservation of the physiological intestinal morphology. Indeed, the duodenum is the intestinal tract that undergoes the fastest cell renewal, and is also the first gut segment to receive the physical, chemical and hormonal stimuli caused by the presence of the diet in the lumen [54]. The obtained results about the preservation of gut histomorphology in all dietary groups contributes to validate what has been previously discussed in terms of nutrient digestibility and growth performances.

\section{Conclusions}

To the best of the authors' knowledge, this is the first study that has evaluated the possibility of including insect meal in duck nutrition, and to have demonstrated how HI larva meal can be a valuable protein sources for ducks. Increasing inclusion levels of a partially defatted HI meal in Muscovy duck diets did not affect the growth performances of the birds, which showed similar LW, ADG, DFI and FCR to the control group fed with corn gluten meal, and only had weak effects on the apparent total tract digestibility during the first stages of growth.
Moreover, these increasing levels did not affect the intestinal morphology or cause histopathological alterations. From this preliminary investigation, it appears that HI larva meal can be included in duck feeding at levels of up to $9 \%$ of the diet, with no negative effects on growth, digestibility or animal health. Furthermore, the obtained results help to expand the information available about the use of insects in poultry nutrition.

\section{Abbreviations \\ ADF: Acid detergent fibre; ADG: Average daily gain; AMEn: Apparent metabolisable energy; ATTDC: Apparent total tract digestibility coefficients; Cd: Crypt depth; CP: Crude protein; DFI: Average daily feed intake; DM: Dry matter; DU: Duodenum; EE: Ether extract; FAME: Fatty acid methyl esters; FCR: Feed conversion ratio; GLMM: General linear mixed model; HE: Haematoxylin \& Eosin; HI: Hermetia illucens; IL: lleum; JE: Jejunum; LW: Live weight; MUFA: Monounsaturated fatty acids; NDF: Neutral detergent fiber; OM: Organic matter; PAS: Periodic acid-Schiff; PUFA: Polyunsaturated fatty acids; SB: Sudan Black; SBM: Soybean meal; SEM: Standard error of the mean; SFA: Saturated fatty acids; TM: Tenebrio molitor; Vh: Villus height; Vh/ Cd: Villus height-to-crypt depth ratio}

\section{Acknowledgements}

The authors would like to thank Mr. Heinrich Katz, the owner of Hermetia Baruth GmbH, Baruth/Mark (Germany), for providing the black soldier fly meal and A.I.A. Agricola Italiana Alimentare S.p.A (Fossano, CN, Italy) for providing the feed ingredients. The authors are also grateful to Mr. Dario Sola and Mr. Mario Colombano for the bird care and technical support.

\section{Funding}

Research supported by the University of Torino (Italy) funding: SCHA_RILO_16_02.

\section{Availability of data and materials}

The datasets analysed in the current study are available from the corresponding author on request.

\section{Authors' contributions}

$M G, S D, F G, L G$ and $A S$ conceived and designed the experiment. MG, SD, LG, $F G, C C, S B O, V R$ and $A S$ prepared the diets, performed the trial and collected the experimental data. MG, SD, FH, JM and SM performed the digestibility determinations. IB, MTC and EC performed the morphometric investigations. AT established the fatty acids profile. MG, SD, IB and MM performed the statistical analysis. LG, FG, AS, MG, SD, AT analyzed and interpreted the data. $L G, M G, S D, I B, A S, F G$ and AT wrote the first draft of the manuscript. All the authors critically reviewed the intellectual content of the manuscript and gave their approval for the final version to be published.

\section{Ethics approval and consent to participate}

The experimental protocol was approved by the Bioethical Committee of the University of Turin (Italy) (protocol number: 380576, 04/12/2017).

\section{Consent for publication}

Not applicable.

\section{Competing interests}

The authors declare that they have no competing interests.

\section{Author details}

${ }^{1}$ Department of Veterinary Sciences, University of Turin, largo Paolo Braccini 2, Turin, Grugliasco 10095, Italy. ${ }^{2}$ Department of Agricultural, Forest and Food Sciences, University of Turin, largo Paolo Braccini 2, Turin, Grugliasco 10095, Italy. ${ }^{3}$ Department of Animal Production, University of Murcia, Campus de Espinardo, 30071 Murcia, Spain. ${ }^{4}$ Institute of Science of Food Production, National Research Council, largo Paolo Braccini 2, Turin, Grugliasco 10095, Italy. ${ }^{5}$ Department of Comparative Biomedicine and Food Science, University of Padua, viale dell'Università 16, Padua, Legnaro 35020, Italy. ${ }^{6}$ A.I.A. Agricola Italiana Alimentare S.p.A, via Val Pantena 18G, 37142 Verona, Italy. ${ }^{7}$ Institute of Interdisciplinary Research on Sustainability, University of Turin, via Accademia Albertina 13, 10100 Turin, Italy. 
Received: 19 December 2018 Accepted: 15 March 2019 Published online: 10 May 2019

\section{References}

1. Alexandratos N, Bruinsma J. World agriculture towards 2030/2050: the 2012 revision. ESA working paper no.12-03. Rome: FAO; 2012.

2. FAOSTAT. 2018. Available from: http://www.fao.org/faostat/en/\#data/QL. Retrieved 6 November 2018.

3. Eurostat. 2018. Available from: http://ec.europa.eu/eurostat/data/database. Retrieved 6 November 2018.

4. Adeola O. Review of research in duck nutrient utilization. Int J Poult Sci. 2006:5:201-18

5. Sánchez-Muros M, Barroso FG, Manzano-Agugliaro F. Insect meal as renewable source of food for animal feeding : a review. J Clean Prod. 2014; 65:16-27.

6. Dossey AT, Morales-Ramos JA, Rojas MG. Insects as sustainable food ingredients: production, processing and food applications. London: Acad Press; 2016.

7. Oonincx DGAB, van Itterbeeck J, Heetkamp MJW, van den Brand $H$, van Loon JJA, van Huis A. An exploration on greenhouse gas and ammonia production by insect species suitable for animal or human consumption. PLoS One. 2010:5:e14445.

8. Meneguz M, Schiavone A, Gai F, Dama A, Lussiana C, Renna M, et al. Effect of rearing substrate on growth performance, waste reduction efficiency and chemical composition of black soldier fly (Hermetia illucens) larvae. J Sci Food Agric. 2018:98:5776-84.

9. De Marco M, Martínez S, Hernandez F, Madrid J, Gai F, Rotolo L, et al. Nutritional value of two insect larval meals (Tenebrio molitor and Hermetia illucens) for broiler chickens: apparent nutrient digestibility, apparent ileal amino acid digestibility and apparent metabolizable energy. Anim Feed Sci Technol. 2015;209:211-8.

10. Cullere M, Tasoniero G, Giaccone V, Miotti-Scapin R, Claeys E, De Smet S, et al. Black soldier fly as dietary protein source for broiler quails: apparent digestibility, excreta microbial load, feed choice, performance, carcass and meat traits. Animal. 2016:10:1923-30.

11. Schiavone A, Cullere M, De Marco M, Meneguz M, Biasato I, Bergagna S, et al. Partial or total replacement of soybean oil by black soldier fly larvae (Hermetia illucens L.) fat in broiler diets: effect on growth performances, feed-choice, blood traits, carcass characteristics and meat quality. Ital J Anim Sci. 2017;16:93-100.

12. Dabbou S, Gai F, Biasato I, Capucchio MT, Biasibetti E, Dezzutto D, et al. Black soldier fly defatted meal as a dietary protein source for broiler chickens: effects on growth performance, blood traits, gut morphology and histological features. J Anim Sci Biotechnol. 2018;9:49. https://doi.org/10. 1186/s40104-018-0266-9.

13. Adeniji AA. Effects of replacing groundnut cake with maggot meal in the diet of broilers. Intenational J Poult Sci. 2007;6:822-5.

14. Hall HN, Masey O'Neill HV, Scholey D, Burton E, Dickinson M, Fitches EC. Amino acid digestibility of larval meal (Musca domestica) for broiler chickens. Poult Sci. 2018:97:1290-7.

15. Biasato I, Ferrocino I, Biasibetti E, Grego E, Dabbou S, Sereno A, Gai F, Gasco L, Schiavone A, Cocolin L, Capucchio MT. Modulation of intestinal microbiota, morphology and mucin composition by dietary insect meal inclusion in free-range chickens. BMC Vet Res. 2018;14:383.

16. Biasato I, De Marco M, Rotolo L, Renna M, Lussiana C, Dabbou S, et al. Effects of dietary Tenebrio molitor meal inclusion in free-range chickens. J Anim Physiol Anim Nutr. 2016;100:1104-12.

17. Biasato I, Gasco L, De Marco M, Renna M, Rotolo L, Dabbou S, et al. Effects of yellow mealworm larvae (Tenebrio molitor) inclusion in diets for female broiler chickens: implications for animal health and gut histology. Anim Feed Sci Technol. 2017:234:253-63.

18. Biasato I, Gasco L, De Marco M, Renna M, Rotolo L, Dabbou S, et al. Yellow mealworm larvae (Tenebrio molitor) inclusion in diets for male broiler chickens: effects on growth performance, gut morphology, and histological findings. Poult Sci. 2018;97:540-8.

19. Barragan-Fonseca KB, Dicke M, van Loon JJA. Nutritional value of the black soldier fly (Hermetia illucens L.) and its suitability as animal feed: a review. J Insects as Food Feed. 2017;3:105-20.

20. Hale OM. Dried Hermetia illucens larvae (Diptera: Stratiomyidae) as a feed additive for poultry. J Ga Entomol Soc. 1973;8:16-20.
21. Schiavone A, Dabbou S, De Marco M, Cullere M, Biasato I, Biasibetti E, et al. Black soldier fly larva fat inclusion in finisher broiler chicken diet as an alternative fat source. Animal. 2018;12:2032-9.

22. Cutrignelli MI, Messina M, Tulli F, Randazzo B, Olivotto I, Gasco L, et al. Evaluation of an insect meal of the black soldier Fly (Hermetia illucens) as soybean substitute: intestinal morphometry, enzymatic and microbial activity in laying hens. Res Vet Sci. 2018;117:209-15.

23. Schiavone A, De Marco M, Martínez S, Dabbou S, Renna M, Madrid J, et al. Nutritional value of a partially defatted and a highly defatted black soldier fly larvae (Hermetia illucens L.) meal for broiler chickens: apparent nutrient digestibility, apparent metabolizable energy and apparent ileal amino acid digestibility. J Anim Sci Biotechnol. 2017;8:897-905

24. Bovera F, Loponte R, Pero ME, Cutrignelli Ml, Calabrò S, Musco N, et al. Laying performance, blood profiles, nutrient digestibility and inner organs traits of hens fed an insect meal from Hermetia illucens larvae. Res Vet Sci. 2018;120:86-93.

25. Wang JX, Peng KM. Developmental morphology of the small intestine of African ostrich chicks. Poult Sci. 2008;87:2629-35.

26. Qaisrani SN, Moquet PCA, van Krimpen MM, Kwakkel RP, Verstegen MW, Hendriks WH. Protein source and dietary structure influence growth performance, gut morphology, and hindgut fermentation characteristics in broilers. Poult Sci. 2014;93:3053-64.

27. Laudadio V, Passantino L, Perillo A, Lopresti G, Passantino A, Khan RU, et al. Productive performance and histological features of intestinal mucosa of broiler chickens fed different dietary protein levels. Poult Sci. 2012;91:265-70.

28. INRA. Tables de composition et de valeur nutritive des matières premières destinées aux animaux d'élevage: porc, volailles, bovins, ovins, caprins, lapins, chevaux, poissons. In: Sauvant D, Perez JM, Tran G, editors. Zème edition revue et corrigée. Paris: INRA Editions; 2004. p. 301.

29. Pingel H, Guy G, Baéza E. Production de canards. 1st ed. France: Éditions Quæ; 2012.

30. AOAC International. Official methods of analysis of AOAC international. 17th ed. Gaithersburg: Association of Official Analytical Chemists; 2002.

31. AOAC International. Official methods of analysis of AOAC international. 17th ed 2nd rev. Gaithersburg: Association of Official Analytical Chemists; 2003.

32. Finke MD. Estimate of chitin in raw whole insects. Zoo Biol. 2007;26:105-15.

33. Madrid J, Martínez S, López C, Orengo J, López MJ, Hernández F. Effects of low protein diets on growth performance, carcass traits and ammonia emission of barrows and gilts. Anim Prod Sci. 2013;53:146-53.

34. Gasco L, Dabbou S, Trocino A, Xiccato G, Capucchio MT, Biasato I, et al. Effect of dietary supplementation with insect fats on growth performance, digestive efficiency and health of rabbits. J Anim Sci Biotechnol. 2019 https://doi.org/10.1186/s40104-018-0309-2.

35. Schiavone A, Chiarini R, Marzoni M, Castillo A, Tassone S, Romboli I. Breast meat traits of Muscovy ducks fed on a microalga (Crypthecodinium cohnii) meal supplemented diet. Br Poult Sci. 2007:48:573-9.

36. Schiavone A, Marzoni M, Castillo A, Nery J, Romboli I. Dietary lipid sources and vitamin $\mathrm{E}$ affect fatty acid composition or lipid stability of breast meat from Muscovy duck. Can J Anim Sci. 2010;90:371-8.

37. Christie WW. A simple procedure for rapid transmethylation of glycolipids and cholesteryl esters. J Lipid Res. 1982;23:1072-5.

38. Kaczmarek SA, Bochenek M, Samuelsson A, Rutkowski A. Effects of glycery polyethylene glycol ricinoleate on nutrient utilisation and performance of broiler chickens. Arch Anim Nutr. 2015;69:285-96.

39. Dabbou S, Schiavone A, Gai F, Martinez S, Madrid J, Hernandez F, et al. Effect of dietary globin, a natural emulsifier, on the growth performance and digestive efficiency of broiler chickens. Ital J Anim Sci. 2018. https://doi. org/10.1080/1828051X.2018.1547127.

40. Marquardt RR. A simple spectrophotometric method for the direct determination of uric acid in avian excreta. Poult Sci. 1983:62:2106-8.

41. Myers WD, Ludden PA, Nayigihugu V, Hess BW. Technical note: a procedure for the preparation and quantitative analysis of samples for titanium dioxide. J Anim Sci. 2004;82:179-83.

42. Nalle CL, Ravindran V, Ravindran G. Nutritional value of white lupins (Lupinus albus) for broilers: apparent metabolisable energy, apparent ileal amino acid digestibility and production performance. Animal. 2012;6:579-85.

43. Ramos-Elorduy J, González EA, Hernández AR, Pino JM. Use of Tenebrio molitor (Coleoptera: Tenebrionidae) to recycle organic wastes and as feed for broiler chickens. J Econ Entomol. 2002;95:214-20.

44. Bovera F, Loponte R, Marono S, Piccolo G, Parisi G, laconisi V, et al. Use of Tenebrio molitor larvae meal as protein source in broiler diet: effect on 
growth performance, nutrient digestibility, and carcass and meat traits. J Anim Sci. 2016;94:639-47.

45. Loponte R, Nizza S, Bovera F, De Riu N, Fliegerova K, Lombardi P, et al. Growth performance, blood profiles and carcass traits of barbary partridge (Alectoris barbara) fed two different insect larvae meals (Tenebrio molitor and Hermetia illucens). Res Vet Sci. 2017;115:183-8.

46. Khan S, Khan RU, Alam W, Sultan A. Evaluating the nutritive profile of three insect meals and their effects to replace soya bean in broiler diet. J Anim Physiol Anim Nutr. 2018;2:e662-8.

47. Elwert C, Knips I, Katz P. A novel protein source: maggot meal of the black soldier fly (Hermetia illucens) in broiler feed. In: Gierus M, Kluth $\mathrm{H}$, Bulang M, Kluge H, editors. Tagung Schweine-und Geflügelernährung, November 2325, 2010. Lutherstadt Wittenberg: Institut für Agrar- und Ernährungswissenschaften, Universität HalleWittenberg; 2010. p. 140-2.

48. Longvah T, Mangthya K, Ramulu P. Nutrient composition and protein quality evaluation of eri silkworm (Samia ricinii) prepupae and pupae. Food Chem. 2011;128:400-3.

49. Tabata E, Kashimura A, Wakita S, Ohno M, Sakaguchi M, Sugahara Y, et al. Gastric and intestinal proteases resistance of chicken acidic chitinase nominates chitin-containing organisms for alternative whole edible diets for poultry. Sci Rep. 2017;7:6662. https://doi.org/10.1038/s41598-017-07146-3.

50. Tabata E, Kashimura A, Kikuchi A, Masuda H, Miyahara R, Hiruma Y, et al. Chitin digestibility is dependent on feeding behaviors, which determine acidic chitinase mRNA levels in mammalian and poultry stomachs. Sci Rep. 2018. https://doi.org/10.1038/s41598-018-19940-8.

51. Leeson S. Recent advances in fat utilization by poultry. In: Farrell DJ, editor. Recent Adv Anim Nutr Aust. Dept. of biochemistry, microbiology and nutrition, University of New England; 1993. p. 170-81.

52. Prola L, Nery J, Lauwaerts A, Bianchi C, Sterpone L, De Marco M, et al. Effects of $\mathrm{N}, \mathrm{N}$-dimethylglycine sodium salt on apparent digestibility, vitamin E absorption, and serum proteins in broiler chickens fed a high- or low-fat diet. Poult Sci. 2013;92:1221-6.

53. Uni Z, Platin R, Sklan D. Functional development of the small intestine in domestic birds: cellular and molecular aspects. Poult Avian Biol Rev. 1999;10:167-79.

54. Murakami AE, Sakamoto MI, Natali MRM, Souza LMG, Franco JRG. Supplementation of glutamine and vitamin E on the morphometry of the intestinal mucosa in broiler chickens. Poult Sci. 2007;86:488-95.

Ready to submit your research? Choose BMC and benefit from:

- fast, convenient online submission

- thorough peer review by experienced researchers in your field

- rapid publication on acceptance

- support for research data, including large and complex data types

- gold Open Access which fosters wider collaboration and increased citations

- maximum visibility for your research: over $100 \mathrm{M}$ website views per year

At $\mathrm{BMC}$, research is always in progress.

Learn more biomedcentral.com/submissions 